\title{
The scientific and educational significance of geoparks as planetary analogues: the example of Lanzarote and Chinijo Islands UNESCO Global Geopark
}

\author{
${ }^{1}$ Instituto de Geociencias, IGEO (CSIC-UCM), Facultad de Ciencias Geológicas C/ José Antonio Novais, 2, Ciudad Universitaria, Madrid \\ 28040, Spain; *Corresponding author, E-mail: j.m.frias@igeo.ucm-csic.es \\ ${ }^{2}$ Lanzarote and Chinijo Islands Geopark, Cabildo de Lanzarote, Avenida Fred Olsen, s/n. Arrecife, Lanzarote Islas Canarias, Spain, E-mail: \\ medioambiente2@cabildodelanzarote.com \\ ${ }^{3}$ Departamento de Cristalografía y Mineralogía, Facultad de Ciencias Geológicas C/ José Antonio Novais, 2, Ciudad Universitaria, Madrid \\ 28040,Spain,E-mail: lunar@ucm.es
}

(Received: February 17, 2017; Revised accepted: March 22, 2017)

http://dx.doi.org/10.18814/epiiugs/2017/v40i4/017035

The new discoveries on other moons and planets (e.g., Mars) are largely supported and guided by the geological knowledge obtained from the study of particular analogue localities on Earth. These planetary analogues show unique geological and environmental conditions, which approximate, in specific ways, to those possibly encountered on other celestial bodies, at the present time or earlier in their geological histories. Such discoveries enrich, through a feedback process, the features of interest of such terrestrial sites, and should be incorporated as innovative scientific and geoeducational aspects of interest to the general public. Many characteristics and particulars of some geoparks can be invaluable for future studies beyond our planet. In this conceptual framework, the present article aims to provide a general overview of studies into planetary analogues carried out in the Lanzarote and Chinijo Islands UNESCO Global Geopark (Canary Archipelago, Spain) and the results obtained, proposing this as a potential model to be followed by other geoparks.

\section{Introduction}

In less than a decade, geoparks have become one of the most exciting and significant geosciences-related areas, with programmes comprising a range of different aspects (e.g., science, geoeducation, geotourism, geoheritage and geoconservation), involving formal institutional support from local and national governments to the highest international level (IUGS, UNESCO). Geoparks are single, unified geographical areas where sites and landscapes of international geological significance are managed with a holistic concept of protection, education and sustainable development (UNESCO, 2016a, p. 3). One the most important aspects of geoparks is that they are not only about geology but about "reconnecting human society at all levels to the planet we all call home and to celebrate how our planet and its 4,600 million year long history has shaped every aspect of our lives and our societies" (UNESCO, 2016a, p. 4).

Likewise, the identification and characterization of terrestrial sites, which can be used as planetary analogues, are currently considered vital study areas of planetary geology and astrobiology. Mars exploration and research well exemplifies these studies, mainly focused on the understanding of its ancient and modern environments and its potential for habitability, from the possible existence of microbes to future human missions.

Among the 120 UNESCO Global Geoparks worldwide, the Lanzarote and Chinijo Islands Geopark (Canary Archipelago, Spain) is the only one which has officially evaluated and characterized specific areas as analogues for the geological and astrobiological exploration and research of Mars. The aim of this work is: 1) to provide a general overview of the main features of the geopark, mainly in the context of its relevance as a planetary analogue; 2) to describe the state-of-theart scientific and educational activities which, in connection with this study, have been carried out at different levels and with diverse objectives (e.g., initiatives for students, public outreach actions, top-level scientific training) and 3) to propose the Lanzarote and Chinijo Islands UNESCO Global Geopark as a potential model to be followed by other geoparks.

\section{Geoparks: Science, Education and Planetary Approach}

It is well-known that the existence of remarkable and internationally important geological outcrops alone is not sufficient for geopark status to be awarded. A geopark is a territory with outstanding geological features and heritage of international significance, and with a development strategy for the benefit of the community (UNESCO, 2016a). In accordance with international regulations (UNESCO, 2012), geopark status is confirmed by scientific professionals. The geologi- 
cal heritage has frequently been revealed through ground-breaking scientific research. Thus, geoheritage, as "set of geological resources with scientific, cultural and/or educational value (geological formations and structures, landscapes, minerals, rocks, fossils, soils, etc.) which allow to know, study and interpret the geological history of the Earth, the processes which have modelled it, past and present climates and landscapes, as well as the origin and evolution of life on this planet" (Águeda Villar et al., 2009, p. 8) is also implicit in this general approach. The significance of geoheritage is well represented in the Global Geosite Project (Wimbledon, 1999) and, in a broader way, in the recent initiative of the International Geoscience and Geoparks Programme, which has been implemented through two activities: the International Geoscience Programme, a co-operative venture with the International Union of Geological Sciences (IUGS), and the UNESCO Global Geoparks (UNESCO, 2016 a, b).

In order to give a general perspective about the subject of geoparks in the scientific literature, a detailed search in the Scientific Thomson Reuters' Web of Science (WoS) database including the keyword "geopark", for papers published in the period 1900-January 2017 was carried out; it yielded a significant number of 332 references. More than $84 \%$ ( 279 records) are incorporated in the WoS'Category of 'Science \& Technology", highlighting the scientific relevance of geoparks and showing a distribution in accordance with the three main WoS Research Areas, which are: Geology (50\%, 166 records), Environmental Science Ecology (21.38\%, 71 records) and Social Science Other Topics ( $16.86 \%, 56$ records). Analysing these results by countries, it is possible to evidence the following five principal ones: China (29.8\%), Italy (6.2\%), Portugal (5.9\%), USA (4.2\%) and Poland (3.9\%).

Geoparks have demonstrated their value as excellent tools, not only for developing important scientific studies, but also in educating the public about earth sciences in multidisciplinary ways, which incorporate recreation and major sustainable economic development through geotourism, together with other societal-related issues, such as mitigating the effects of climate change and reducing natural disastersrelated risks. Geoscience education is a key factor in the academic, scientific and professional progress of any modern society (AGI, 2004; Hoffman and Barstow, 2007; NSF, 2010; Martinez-Frias and Mogessie, 2012; Bickford, 2013; Vasconcelos, 2016). The scienceeducation link is a common and crucial characteristic of geoparks. Many geoparks hold scientific and technological training courses (e.g., Leye Fengshan UNESCO Global Geopark, China) and, in other cases, partnership and cooperation with scientific institutions (e.g., Swabian Alb UNESCO Global Geopark, Germany) have been established, bringing scientific geological (and cultural) information to the public through a range of activities including geosites, museums, educational materials, guided traverses, talks and seminars and round tables, among others (see, for instance, Geoparks, https://cursosonline.uminho.pt/EN/geoparksInternational Intensive Course on Geoparks http://www.petrifiedforest.gr/geoparks2016/, $2^{\text {nd }}$ Regional Training Courses on UNESCO GLOBAL GEOPARKS, http://www.globalgeopark.org/ News/Events/10769.htm). Geoparks can be a perfect tool for communicating geoscientific knowledge and environmental and cultural concepts to the public. Many geoparks also foster scientific research and educational cooperation with universities, a wide discipline of scientists and academic organizations (UNESCO, 2014). If, in a second stage the WoS database analysis, we include the keywords "Geopark" and "Education" the numbers decrease dramatically. Only 43 references/records appear for the same period of time, with the following results for the main five WoS Research Areas: Geology (22), Social Sciences and Other Topics (11), Environmental Sciences, Ecology (7), Geography (6) and Biodiversity Conservation (4). This confirms the need for developing further educational activities.

Finally, in the context of planetary and space approaches, there are some geoparks which display some geological features related to cosmic-bearing events (e.g., Swabian Alb UNESCO Global Geopark, Ries impact crater, Stoffler et al., 2008; Basque Coast UNESCO Global Geopark, K/T boundary, Zumaia area, Schmitz, 2011). So far we do not know of a place on Earth which is truly like Mars or any other planet in our solar system (Martínez-Frías, 2015). Nevertheless, it is possible to identify terrestrial analogue sites, where environmental conditions approximate, in particular ways, to those possibly encountered on other celestial bodies, in the present day or earlier in their geological histories. Many sites have been used with this purpose with different perspectives (e.g., Antarctica, Río Tinto, Atacama, Australia, Jaroso, Svalbard, Hawaii, among others) (Clarke, 2006; Chapman, 2007; Garry and Bleacher, 2011; Preston et al., 2012). These sites are also important areas for defining scientific models and testing new instrumentation, applying geoethical protocols and paving the way for understanding planetary processes and past and present habitability conditions, including future human-related issues (Martínez-Frías, 2016).

A third stage of the analysis of the WoS database including the keyword "Geopark" with planetary and space-related terms, such as "Planetary", "Mars" or "Astrobiology" was performed. No records were yielded by these searches. Hence, the present article constitutes probably the first contribution linking geoparks with their planetary significance; the studies linked to Mars which were carried out in the Lanzarote and Chinijo Islands UNESCO global Geopark exemplify these links very well.

\section{The Lanzarote and Chinijo Islands UNESCO Global Geopark: Planetary Significance}

The geopark covers an area of more than $2,500 \mathrm{~km}^{2}$, comprising $866 \mathrm{~km}^{2}$ of the island of Lanzarote and the small islands of La Graciosa, Montaña Clara, Roque del Este, Roque del Oeste and Alegranza, located in the north, known as "Chinijo Islands". The Lanzarote Geoscience Laboratory, a joint facility of the Institute of Geosciences, IGEO (CSIC: Spanish "Consejo Superior de Investigaciones Científicas" - UCM: Complutense University of Madrid) and the "Cabildo Insular de Lanzarote" (local administration), opened a study into planetary analogues in October 2013, in connection with the ongoing activities of the Spanish CSIC Research Group of "Meteorites and Planetary Geosciences". The main idea was to explore the remarkable geoscientific resources and excellent preservation features of the area, through an innovative planetary approach to be used as a natural laboratory and a potential analogue in relation to the exploration and research of Mars. In this framework, "planetary" research was initiated in Lanzarote, with the objective of establishing an agreement between the IGEO and the Cabildo of Lanzarote. Almost in parallel, the Lanzarote and Chinijo Islands Geopark was presented as a candidate in 2013 (also in October) to become a new member of the Euro- 
pean and Global Geoparks Networks. It is important to note that the planetary significance of this territory was specifically included in the additional documentation, which was submitted in March 2015 aiding its final approval as a geopark (EGN/GGN: September/2015 and UNESCO: November/2015).

Volcanism and liquid water-related processes were particularly important and active on Mars during the first stages of evolution of the red planet (Martínez-Frías, 2016). Some Martian areas show widespread evidence of hydrovolcanism and hydrothermal activity (Broz and Hauber, 2013). The Canary Archipelago is one with higher geodiversity and interesting chain of oceanic islands worldwide, displaying a long history of eruptions and a huge variety of: 1) volcanic and plutonic rocks (the islands are dominated by basaltic rocks, but show a great petrologic and geochemical diversity including alkaline basalts (some of them showing tholeiitic tendencies), trachybasalts, basanites, tephrites, rhyodacites, rhyolites, trachytes, phonolites and carbonatites); 2) geomorphological features and volcanic edifices and 3) a high diversity of geological processes. Several areas of the Canary archipelago had been (and still are) used as analogue sites for performing scientific and engineering studies, in relation with the exploration and research of Mars and the Moon. They included: a) geological, mineralogical, geochemical and astrobiological studies of volcanic rocks, rock-fluid interactions and mineralization processes; b) operational and instrumentation activities, such as field testing of rovers and the use of portable spectroscopic prototypes (e.g., Raman), and c) the use of volcanic materials (e.g., basaltic rocks and soils) for the fabrication of asteroidal, lunar and Martian regolith simulant (Bustillo and Martínez-Frías, 2003; Rodríguez-Losada et al., 2010; Martínez-Frías et al., 2012, 2014; Lalla et al., 2016). However, among all islands, Lanzarote is, to our knowledge, the best site which better exemplifies the scientific, educational and social relevance of the whole archipelago as a planetary analogue and which can be used as a field geological museum and a natural laboratory (Fig. 1).

The planetary-related activities which have been carried out in the Lanzarote and Chinijo Islands UNESCO Global Geopark comprise scientific, educational and public outreach initiatives, such as: 1) public talks and seminars focused on students; 2) round-table and open debates for the general public and 3) launching of a pioneering field

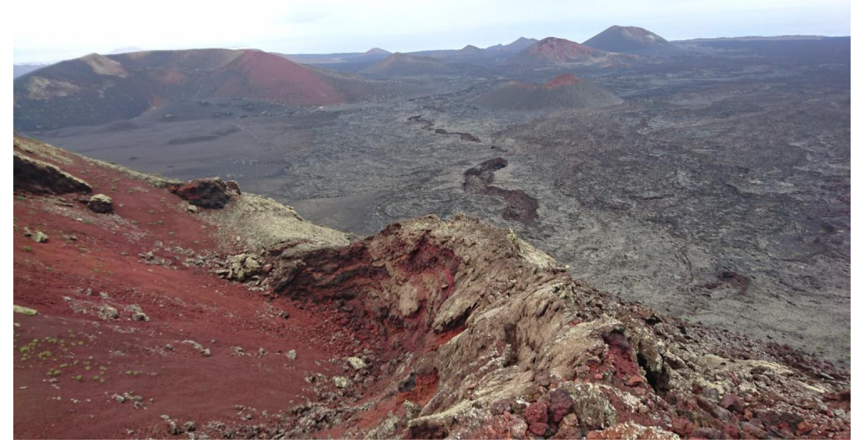

Figure 1. Panoramic view of Timanfaya (Lanzarote island): part of one of the most impressive and well-preserved volcanic parks in the world. Timanfaya comprises more than 25 volcanoes. The Timanfaya eruption (1730-1736), the longest recorded in the Canary Archipelago, was mainly characterized by basaltic flows with tholeiitic tendencies. The eruptions have created a spectacular Martian-like landscape.

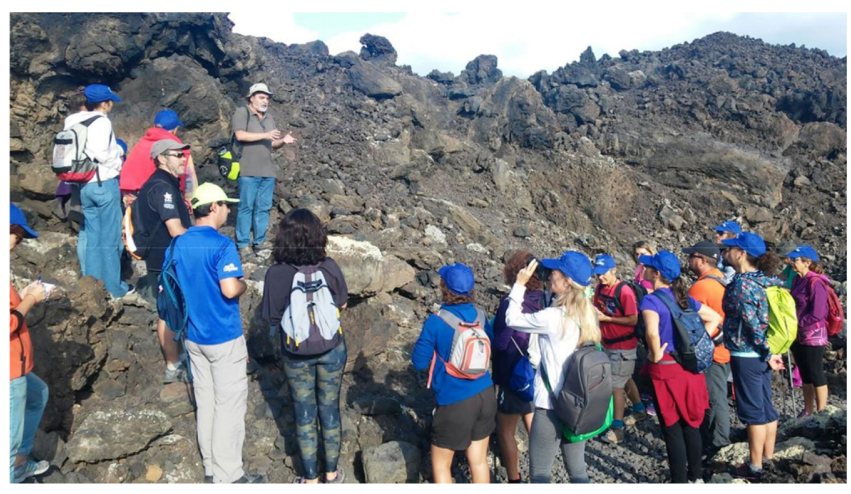

Figure 2. One of the main methods used to highlight the planetary significance of the geopark has been the design of planetary routes, using the same classical volcanic elements as other routes, but with a different approach, with a wider vision of the geological processes and their planetary implications.

project, which basically consists of planning and designating "planetary (Martian) routes" (Martínez-Frías et al., 2016; Martínez-Frías and Mateo-Mederos, 2016) (Fig. 2) to be incorporated in the more classical geotouristic field activities of the geopark. The new discoveries on the Moon and other planets (e.g., Mars) are supported and guided by geological knowledge of the planetary analogues on our planet. Thus, the findings enrich, through a feedback process, the features of interest of such terrestrial sites, and should be also incorporated as innovative scientific, educational and general cultural aspects for educating the general public.

A framework has been devised to integrate basic geoscientific and geoeducational approaches for establishing routes in the geopark involving the following aspects, which link volcanism and water, as envisaged for the early wet Martian environment and its habitability potential: a) characterization of geomorphological and petrological features of volcanic edifices, mainly those related with water (e.g., hydrovolcanism); b) volcanism-related hydrothermal sites and their mineralization, explaining their mineralogical and geochemical characteristics, making, in particular, the comparison between fresh and altered rocks (Figs. 3 and 4), and also describing neo-formed hydrothermal mineral phases; c) altered zones due to low-temperature interaction between meteoric or marine water with volcanic rocks; d) study of lava tubes (at different scales), taking into account their potential astrobiological relevance (e.g., special habitats which are

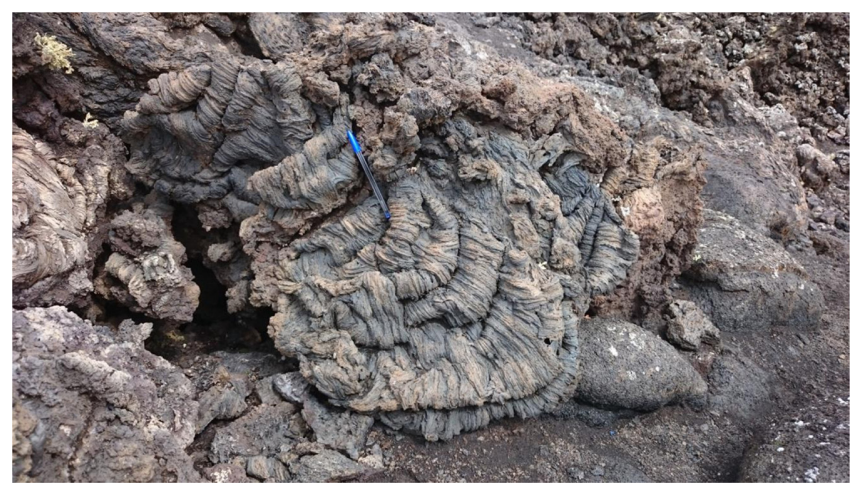

Figure 3. Details of fresh recent lavas showing classical pahoe-hoe texture, which crop out near the area of Montaña Señalo (Lanzarote). 


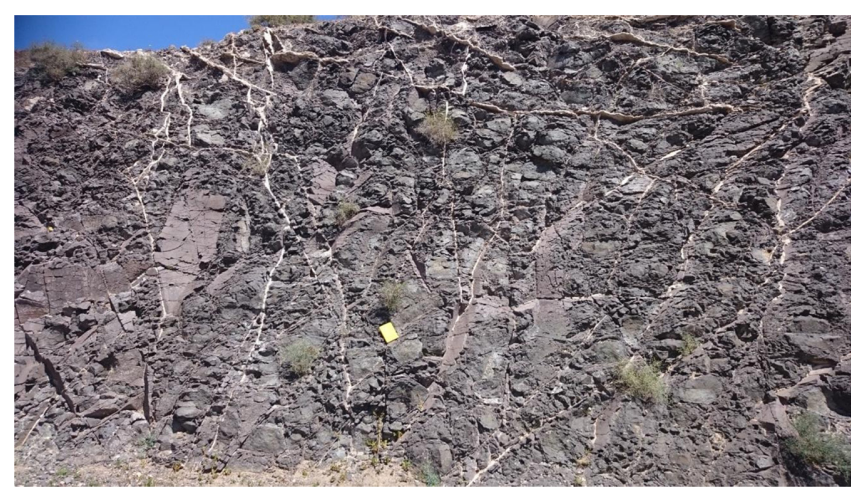

Figure 4. Altered outcrop characterized by intersecting mineral veins affecting ancient basaltic rocks in the Ajaches area (South Lanzarote).

shielded from radiation and other harsh environmental conditions for life), and e) integration of all these aspects, through considering geoethical issues and protocols (Martínez-Frías et al., 2011) involving consideration of accessibility conditions to ensure equal access for everyone (Atchison and Martínez-Frías, 2012).

One of the best recent examples relating science and education was the use of some of the planetary routes of the Lanzarote and Chinijo Islands UNESCO Global Geopark for the training of European Space Agency (ESA) Astronauts. This approach was developed as part of the framework of the PANGAEA (Planetary ANalogue Geological and Astrobiological Exercise for Astronauts) Course: PANGAEA is "designed to provide European astronauts with introductory and practical knowledge of Earth and planetary geology to prepare them to become effective partners of planetary scientists and engineers in designing the next exploration missions. The course also aims to give astronauts a solid knowledge in the geology of the Solar System from leading European scientists" (ESA-PANGAEA, 2016). This ESA Course is an innovative initiative, which supersedes the old classical geological training activities carried out by NASA Apollo astronauts mainly during the 1960s (Phinney, 2015). Clearly there is now, in the $21^{\text {st }}$ century, a great opportunity for showing how the features of particular geoparks can be invaluable in investigations for future operations beyond our planet. Specifically considering the Lanzarote model, it is suggested to develop similar planetary-related studies focused on geoparks in which the volcanism-water interactions are well represented and preserved. Nevertheless, the use of earth analogues covers multiple aspects, from specific minerals or geological structures to wide regional features (Preston et al., 2012), widening this planetary approach to many other geoparks.

\section{Final Remarks}

Only geoscientists can effectively extrapolate the scientific and geoeducational significance of terrestrial localities to other celestial bodies. The geological exploration of other planets demonstrates that the Earth is a system but also a model, in which basic geological principles are of extreme importance for developing understanding of other planets. This approach is already underway (e.g., for Mars), but it will take many years to complete, through providing a wider picture of the geological issues at a planetary scale. Given that the Inter- national Geoscience and Geoparks Programme (IGGP) is being implemented through the International Geoscience Programme, a cooperative project with the International Union of Geological Sciences (IUGS), and the UNESCO Global Geoparks, we feel Episodes provides a perfect platform for calling all UNESCO Global Geoparks and other international institutions, organizations, societies or associations related to them, to develop the significance of geoparks through novel scientific and educational activities related to planetary and space exploration and research.

\section{Acknowledgements}

This work forms part of the activities carried out through the Lanzarote Geoscience Laboratory through the framework of the official Agreement between the Cabildo de Lanzarote and the Institute of Geosciences (IGEO). Our special thanks to the Lanzarote and Chinijo Islands Geopark and "Casa de los Volcanes", especially to Jaime Arranz, Orlando Hernandez and Clara Bonilla. Also thanks to all members and colleagues of the ESA-PANGAEA Course, in particular to Loredana Bessone and Francesco Sauro and to Prof. Chris King for his revision and useful remarks. Finally, we thank the two referees (Profs. José Brilha and Paulo Tricão) for their thoughtful and useful comments, which have greatly improved the original manuscript.

\section{References}

AGI, 2004, Why Earth Science?: https://www.agiweb.org/education/ WhyEarthScience/Why_Earth_Science.pdf

Atchison, C., and Martinez-Frias, J., 2012, Inclusive geoscience instruction: Nature Geoscience, v. 5, no. 6, pp. 366.

Águeda Villar, J.A., García Cortés, A., and Palacio Suarez Valgrande, J., 2009, Introduction. in García-Cortés, A. (ed.), Spanish Geological Frameworks and Geosites. An Approach to Spanish Geological Heritage of International Relevance: Instituto Geológico y Minero de España (IGME), Madrid, pp. 7-13.

Bickford, M.E., 2013, The impact of the geological sciences on society: The Geological Society of America, Special Paper, v. 501, 200 p.

Broz, P., and Hauber, E., 2013, Hydrovolcanic tuff rings and cones as indicators for phreatomagmatic explosive eruptions on Mars: Journal of Geophysical Research, v. 118, pp. 1656-1675.

Bustillo, M.A., and Martínez-Frías, J., 2003, Green opals in hydrothermalized basalts (Tenerife Island, Spain): alteration and ageing of silica pseudoglass: Journal of Non-Crystalline Solids, v. 323, pp. 27-33.

Chapman, M., 2007, The Geology of Mars. Evidence from Earth-based Analogues: Cambridge University Press, New York, 460 p.

Clarke, J.D.A., 2006, Mars Analogue Research: Americal Astronautical Society by Univelt, San Diego, $343 \mathrm{p}$.

ESA-PANGAEA, 2016, Caves and Pangaea: http://blogs.esa.int/caves/ category/pangaea/

Hoffman, M., and Barstow, D., 2007, Revolutionizing Earth System Science Education for the 21st Century: Report and Recommendations from a 50-State Analysis of Earth Science Education Standards, TERC, Cambridge, $59 \mathrm{p}$.

Lalla, E.A., Lopez-Reyes, G., Sansano, A., Sanz-Arranz, A., Martínez-Frías, J., Medina, J., and Rull, F., 2016, Raman-IR vibrational and XRD characterization of ancient and modern mineralogy from volcanic eruption in Tenerife Island: Implication for Mars: Geoscience Frontiers, v. 7, no. 4, pp. 673-681.

Garry, W.B., and Bleacher, J.E., 2011, Analogues for planetary explora- 
tion: Geological Society of America, Special Paper, v. 483, 567 p.

Martinez-Frias, J., González, J.L., and Rull, F., 2011, Geoethics and deontology: from fundamentals to applications in planetary protection: Episodes, v. 34, no. 4, pp. 257-262.

Martinez-Frias, J., and Mogessie, A., 2012, The need for a geoscience education roadmap for Africa: Episodes, v. 35, no. 4, pp. 489-492.

Martínez-Frías, J., Rodríguez-Losada, J.A., Rull, F., and Eff-Darwich, A., 2012, The pumice-like unusual pyroclasts from El Hierro submarine eruption (Canary Islands): Hydrothermal signature, new genetic insights and astrobiological significance (abs.): $34^{\text {th }}$ International Geological Congress, Terrestrial Planets and Habitability Symposium, Brisbane.

Martínez-Frías, J., Rodriguez-Losada, J.A., Ortega, C., and Carrera, M., 2014, Experimental make-up of a regolith simulant from CI carbonaceous chondrite composition: mineralogicalfeatures and significance for sampling of C-type asteroids (abs.): $21^{\text {st }}$ General Meeting of the International Mineralogical Association (IMA 2014), Joannesburg.

Martínez-Frías, J., 2015, Search for life on Mars: an astrogeological approach. in Kolb, V. (ed.), Astrobiology: An Evolutionary Approach: CRC Press, 504 p.

Martínez-Frías, J., 2016, Lanzarote planetary analogue: a geological museum and a natural laboratory for Mars: CAVES \& PANGAEA, European Space Agency (ESA). http://blogs.esa.int/caves/2016/12/05/lanzaroteplanetary-analogueue-a-geological-museum-and-a-natural-laboratory-for-mars/

Martínez-Frías, J., and Mateo-Mederos, MaE., 2016, Mars-related routs in Lanzarote and Chinijo Island Global UNESCO Geopark (abs.): $7^{\text {th }}$ International Conference on UNESCO Global geoparks: English Riviera UNESCO Global Geopark.

Martínez-Frías, J., Mateo Mederos, MaE., and Lunar, R., 2016, Los geoparques como áreas de investigación, geoeducación y geoética en geociencias planetarias: el geoparque de Lanzarote y Archipiélago Chinijo (abs.): IX Congreso Geológico de España, Huelva.

NSF, 2010, Earth Science Literacy Principles. http://www.earthscienceliteracy.org/

Phinney, W.C., 2015, Science Training History of the Apollo Astronauts: NASA/SP-2015-626. https://www.hq.nasa.gov/alsj/PhinneySP-2015626.pdf

Preston, L., Barber, S., and Grady, M., 2012, CAFE Concepts for Activities in the Field for Exploration: The Planetary and Space Sciences Research Institute, The Open University, UK. ESA Contract \# 4000104716/11/ NL/AF, 170 p.

Rodriguez-Losada, J.A., Hernández, S., Martínez-Frías, J., Hernández, L.E., Lunar Hernández, R., 2010, Study of lunar soil from terrestrial models (Canary Islands, Spain). in Olalla, C., Hernández, L., Rodríguez-Losada, J.A., Perucho, A., and González Gallego, J. (eds.), Volcanic Rock Mechanics. Rock Mechanics and Geo-Engineering in Volcanic Environments: CRC Press, 368 p.

Schmitz, B., Pujalte, V., Molina, E., Monechi, S., Orue-Etxebarria, X., Speijer, R., Alegret, L., Apellaniz, E., Arenillas, I., Aubry, M.P., Baceta, J., Berggren, W.A., Bernaola, G., Caballero, F., Clemmensen, A., DinarèsTurell, J., Dupuis, C., Heilmann-Clausen, C., Hilario-Orús, A., Knox, R., Martín-Rubio, M., Ortiz, S., Payros, A., Petrizzo, M.R., von Salis, K., Sprong, J, Steurbaut, E., and Thomsen, E., 2011, The global stratotype sections and points for the bases of the Selandian (Middle Paleocene) and Thanetian (Upper Paleocene) stages at Zumaia, Spain: Episodes, v. 34, no. 4, pp. 220-243.

Stöffler, D., Pösges, G., and Barfeld, R., 2008, Developments of geotourism in the national Geopark Ries, Southern Germany (abs.): Large Meteorite Impacts and Planetary Evolution IV, Vredefort Dome, South Africa. 3070.pdf

UNESCO, 2012, Statutes of the International Geoscience and Geoparks Programme (IGGP): http://www.globalgeopark.org/UploadFiles/2012_9_ 6/IGGP_EN_Statutes_and_Guidelines.pdf

UNESCO, 2014, Global geoparks Network. Guidelines and Criteria for National Geoparks seeking UNESCO's assistance to join the Global
Geoparks Network (GGN): http://www.europeangeoparks.org/wp-content/ uploads/2012/03/Geoparks_Guidelines_Jan2014.pdf

UNESCO, 2016a, UNESCO Global Geoparks. Celebrating Earth Heritage, Sustaining local Communities: http://www.globalgeopark.org/ UploadFiles/2016_2_16/ UNESCO\%20Global\%20Geopark\%20Brochure.pdf

UNESCO, 2016b, Earth Sciences. International Geosciences and Geoparks Programme (IGGP): http://www.unesco.org/new/en/natural-sciences/ environment/earth-sciences/international-geoscience-and-geoparksprogramme/

Vasconcelos, C., 2016, Geoscience Education: Indoor and Outdoor: Springer, $236 \mathrm{p}$.

Wimbledon, W.A.P., 1999, GEOSITES - an International Union of Geological Sciences initiative to conserve our geological heritage: Polish Geological Institute Special Papers, v. 2, pp. 5-8.

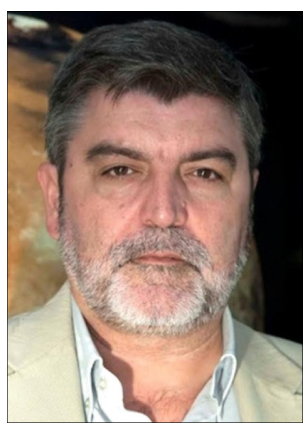

Jesús Martínez-Frías is Scientific Researcher at IGEO (CSIC-UCM) and director of the Spanish Planetology and Astrobiology Network. More than 40 projects and scientific campaigns (e.g., Antarctica, Mauritania, Iceland). In 2002, he participated in the NASA flight to study the Leonid Meteor Shower. He is co-I in NASA-MSL (rover Curiosity), ESA-ExoMars and NASA-Mars2020. He has published 8 books and more than 200 articles (Science, Nature, Geology, Episodes, etc.). Former Member of the UN ECOSOC Committee on Natural Resources, Ex-ViceChair of the UNCSTD and Ex-Chair of IUGS-COGE. He is President of the IAGETH. He has received several awards and recognitions (NASA, ESA, GSAf, ArabGU).

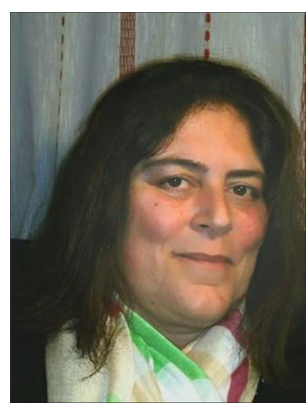

Elena Mateo Mederos is BSc in Geology. Responsible and Scientific Coordinator at Lanzarote and Chinijo Islands UNESCO Global Geopark. Expert on Environmental Impact. Responsible for the protected Lanzarotenatural areas. She was in charge of Management and Direction of Nature School in Máguez (Lanzarote). Manager of research, interpretation, dissemination of geological heritage, including the museum of Canarian volcanism. She has participated in European projects (e.g., Development of Educational Resources.Canary Volcanism and Restoration of islets and cliffs of Famara). Science Committee Member of the Spanish Planetology and Astrobiology Network. Editorial Board Member of the Journal "Canary Environment". She has published 10 articles and books.

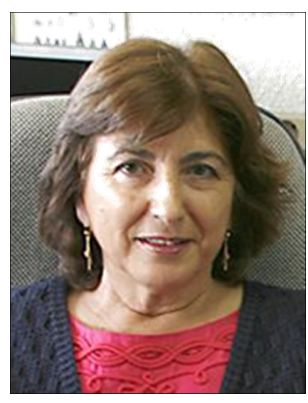

Rosario Lunar is $\mathrm{PhD}$ in Economic Geology. Full Professor at UCM and Director of IGEO (CSIC-UCM). Expert on metallogenetic processes associated to magmatic and hydrothermal systems. Former Vicepresident, EMU. Ex-Coordinator (Spain), InterRidge. Former Secretary, Faculty of Geology. Ex-coordinator of the quality mention UCM' $\mathrm{PhD}$ program "Geological Processes and Resources". ExDirector, Dept. Crystallography and Mineralogy. Ex-Coordinator, Area of Earth Sciences (ANEP). Former President, Evaluation Board (ANECA). Numerary Member, Spanish Royal Academy of Doctors. Board Member, Madrid Science Park. PI of numerous public research projects and private contracts. Supervisor of $17 \mathrm{PhD}$ theses and more than 20 Master and Degrees. More than 200 articles (100 in SCI journals) and books. 